\title{
KASHMIR SAPPHIRE
}

\author{
By David Atkinson and Rustam Z. Kothavala
}

The unique beauty of gem sapphires from Kashmir has brought fame to a locality about which little has been reported in recent years. After an initial burst of activity 100 years ago, the production of these gemstones has slowed to a trickle and the majority of the corundum from these mines today is of industrial grade. Despite evidence of other gem mineral occurrences in the area, difficult terrain and political factors have impeded their exploitation. This article, the result of an expedition to the deposits in 1981. chronicles the history of the Kashmir mines, describes the characteristics of the sapphires found there, and examines the outlook for the future of this area.

\section{ABOUT THE AUTHORS}

Dr. Kothavala, formerly lecturer on geology and director of the Science Center at Harvard University, is the owner of Crystals of India, a firm that specializes in mineral and gem specimens from India, and Rustam, a mineralogical consulting firm, in Oakland, California.

Mr. Atkinson is the owner of Terra, a firm specializing in rare gems and gem minerals, in Santa Barbara, California.

Acknowledgments: The authors are indebted to Meher, without whose material aid and contacts the expedition could not have succeeded. Dr. R. $\checkmark$. Gaines has generously provided specimens, references, and critical commentary. Acknowledgment is also due to R. Miller, of Reginald C. Miller, Inc., New York, for his observations; J. Koivula, of the Gemological Institute of America, for his study of the Hixon Kashmir sapphire; Si and Ann Frazier, of Berkeley, California; and the Los Angeles County Museum of Natural History for their cooperation. The expedition owes its initial inspiration, in 1973, to R. A. Bideaux of Tucson and Professor Clifford Frondel of Harvard University.

1983 Gemological Institute of America
S ince their discovery in 1881, the legendary sapphire $\mathcal{O}$ deposits of Kashmir have acquired a reputation based on a mixture of fact and fantasy that is usually associated with the ancient gem mines of the world. Situated in the high Himalaya Mountains of northwest India and described in early reports as "the region beyond the snows," the locality is so remote that to this day only a handful of trained geologists have visited the site. Consequently, little has been published on the deposits in recent years and even less on the stones mined there. Because outsiders were strictly forbidden to enter the Paddar region of Kashmir until 1979, Dr. Kothavala's earlier efforts to visit the sapphire deposits were refused. In 1981, he invited Mr. Atkinson to join him in a renewed attempt to reach the mines. Until the authors' visit during the summer of 1981, the last known Westerner to inspect the site was R. V. Gaines in 1944. Accounts of that trip were published in 1946 and 1951 (Gaines). First reports, although informative and detailed, pertain only to the early years and lie scattered among the voluminous records of government geologists during the days of the British raj. More recently, in 1961, the state government of Jammu and Kashmir undertook a detailed feasibility survey, but the results of this study remain confidential. One reason for the dwindling worldwide interest in these mines is the paucity of fine gems produced after 1908. Such scarcity would long ago have doomed the locality to insignificance were it not for the unique beauty of the few stones that still emerge. Similarly, the inaccessibility of the mines is tempered only by the awe-inspiring beauty of their surroundings. Even the 19th-century geologists felt compelled to devote entire paragraphs to describe carpets of wildflowers and majestic scenery in their otherwise staid reports.

Few gemologists would dispute that a fine Kashmir stone displays a character that sets it apart in a world relatively abundant in corundum gems (figure 1). Over the years, the term Kashmir has come to signify the most desirable and expensive of blue sapphires. The protracted 
territorial dispute between India and Pakistan over the state of Kashmir, plus the outlawing of private trade in Kashmir sapphires since the early 1880 s by the maharajah, have conspired to surround the mining and trading of these stones with an aura of secrecy and suspicion. Add to that the extreme cultural isolation of the local people, whose small villages lie in narrow valleys among mountains that rise to more than $6,000 \mathrm{~m}\langle 20,000$ $\mathrm{ft}$ ), and one has the necessary ingredients for a legend that compares with Shangri-La (figure 2).

The purpose of this article is to set the particular conditions pertaining to the area in perspective. It seeks to chronicle the major developments at this occurrence in the 100 years since its discovery, review what little literature exists on the subject, and provide some insights into the very limited but continuing trade in Kashmir sapphires today. In addition, a brief commentary on the geology of the area and a discussion of the gemological characteristics of Kashmir stones are provided.

\section{HISTORY}

As early as 1882 (Mallett) and 1890 (La Touche), reports by government geologists to the Geological Survey of India concurred that the discovery of sapphires in a glacial cirque above the village of Sumjam, on the southwest slopes of the rugged Zanskar Range (figure 3), was the result of a land-

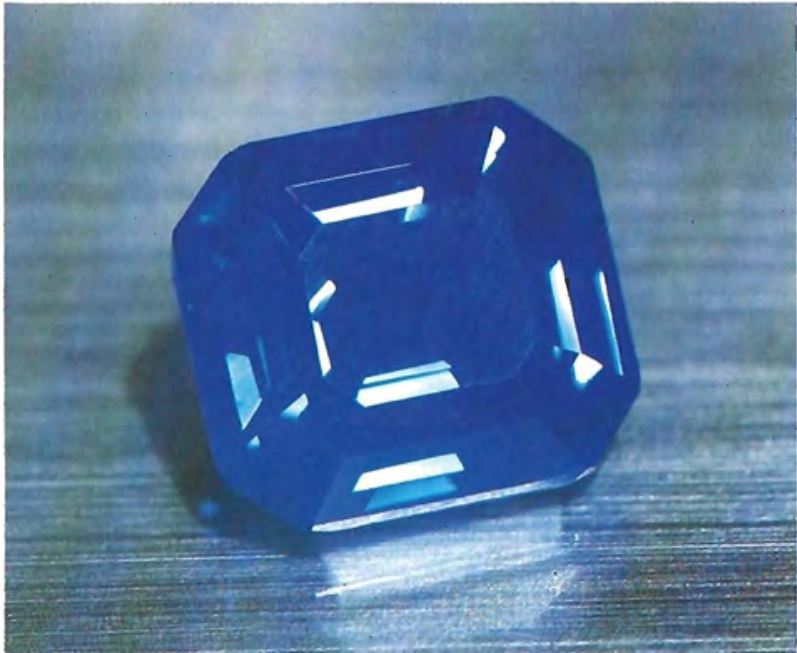

Figure 1. This 6.7-ct sapphire from the Hixon Collection at the Los Angeles Museum of Natural History displays the distinctive velvety texture for which Kashmir stones are renowned. Photograph "1978 Harold and Erica Van Pelt-Photographers, Los Angeles, CA.

slide that took place some time in 1881 /see chronology in box). Minor quakes and avalanches are frequent in this geologically active region. It is clear from various letters and communications by missionaries and traders who lived in the area at the time that the local inhabitants had been aware

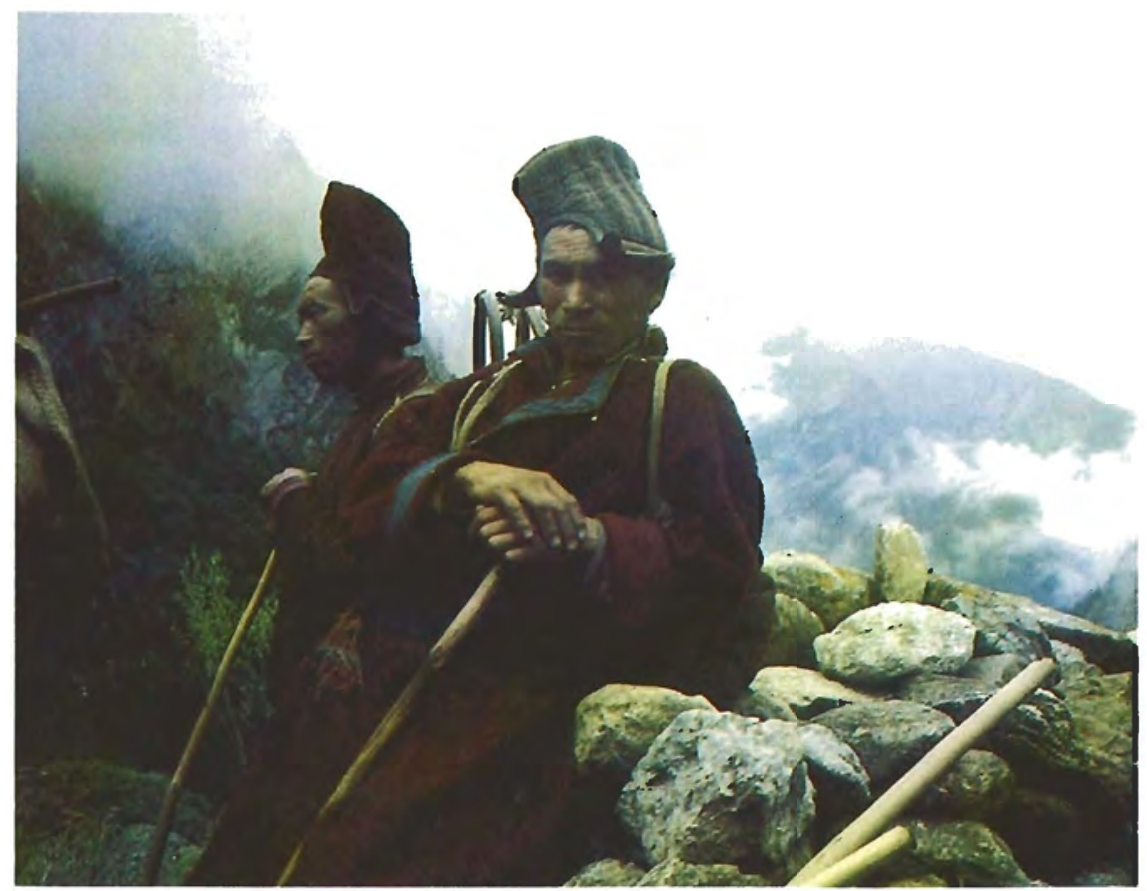

Figure 2. Zanskari traders, crossing the high mountain passes, were first responsible for bringing the sapphires from Paddar to the attention of the outside world. Photo by Meher. 

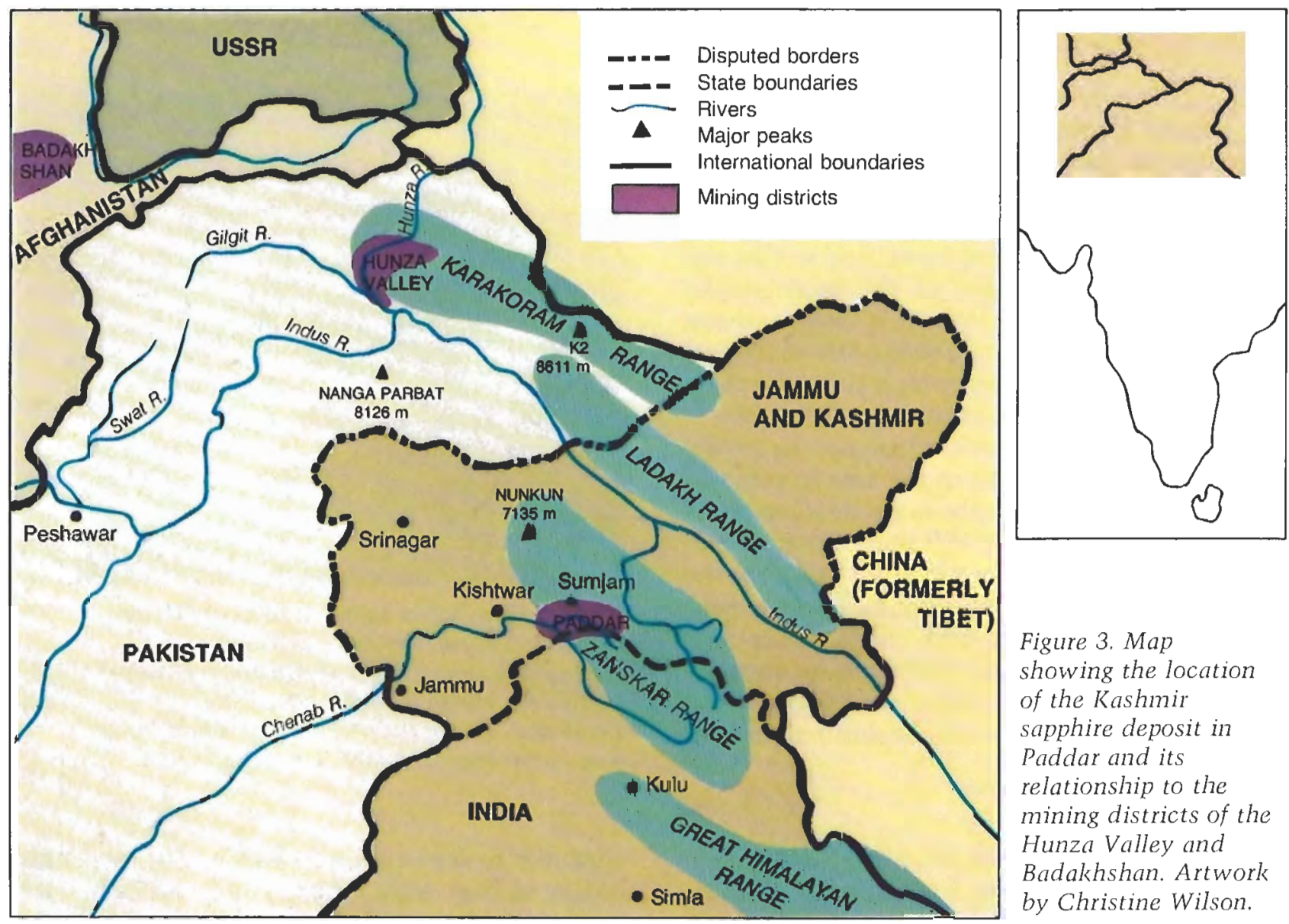

of several different corundum deposits (Mallett, 1882; Shepard, 1883). Conversations with villagers during the expedition in 1981 verified that opaque, grayish corundum crystals had been used as flints and as crude abrasive tools from very early times. The exposure in 1881 of a concentrated pocket of gemmy blue crystals sparked enough local excitement to initiate exchanges with itinerant traders from the neighboring valleys of Zanskar and Lahul. After crossing the Umasi-La Pass $(5,290 \mathrm{~m})$ in order to reach Sumjam, in the valley of Paddar, these merchants were at first skeptical and had to be cajoled into trading the nilam ("blue stone") for salt on a weight for weight basis. Eventually, these stones found their way to larger commercial centers, usually in the company of more traditional and humble minerals, notably borax and salt. It was in the marketing centers of Kulu and Simla /the summer capital of Indial that the crystals were positively identified and their true value recognized. The news spread quickly. By the end of 1882, a syndicate of jewelers had paid the equivalent of US\$90,000 for a lot of fine crystals (Mallett, 1882).
From these reports it can be inferred that the early production was quite abundant.

By 1883 , the maharajah of Kashmir had claimed his rightful ownership of the mines and declared all private trade in the stones a punishable offense. Not surprisingly, the local Paddaris, disconnected from affairs of state, deeply resented the stationing of a contingent of the maharajah's elite Dogra guards at the mine. This sentiment persists still in the valley, where the authors had the opportunity to talk with both the local villagers and the police stationed at the mines. Until 1887, various government officials were dispatched to the mine to oversee the collection of sapphire on behalf of the state and to prevent rampant smuggling and raiding of the site, which later became known as the Old Mine (figure 4). Their efforts reaped enormous wealth for the state, and led to the fabled collection of crystals and gems held at the state treasury (some of which are described later in this article). As dramatically as it had begun, production slowed to a trickle as the initial pocket of sapphire was worked out. In 1887, the Kashmir Durbar acquired the services 


\section{CHRONOLOGY OF THE KASHMIR DEPOSITS}

1881 A landslip exposes blue crystals embedded in altered pegmatites high on the north wall of the cirque. Local villagers begin trading for consumer goods. Tibetans from Zanskar trade salt for sapphires, weight for weight. Crystals begin to appear in Kulu, to the south.

1882 Crystals begin to appear in Simla, where syndicates of jewelers rush to buy them. About this time, the maharajah of Kashmir dispatches troops to guard the mine and prohibit dealing.

1883- Mining operations are in the hands of the 1887 maharajah's army officers. Crystals up to $12.5 \mathrm{~cm}$ long and $7.5 \mathrm{~cm}$ wide are dug from the site, which would later become known as the Old Mine. The finest large stones are recovered during this period.

1887 T. D. La Touche undertakes the first detailed survey of the deposits for the Geological Survey of India in response to a request for assistance by the Kashmir Durbar.

He finds the initial pocket exhausted and turns his attention to the exploitation of placers, which lie below the scree and talus on the valley floor. In the process, the last great sapphire, a 933-ct parti-colored stone, is found.

1888 La Touche's ingenious attempt to create a fresh landslide to uncover new deposits fails. During the summer of $1888,23,300 \mathrm{ct}$ of sapphire are mined, but the material yields few stones over $10 \mathrm{ct}$.

1889- A 16-year lull in official operations. The 1906 flow of sapphires is restricted to illegal activities.

1906 The first mining by private interests is permitted. The maharajah of Kashmir grants a lease to the Kashmir Mining Company. The company's mining engineer, C. M. P. Wright, after detailed analyses, reworks the earlier placer deposits and obtains many fine stones.

1907 An experimental trench is dug a few hundred meters to the southeast of the Old Mine. Although some corundum crystals are discovered, the potential value of what will later be known as the New Mines complex goes unnoticed.

1908 Difficulties of climate and conditions force Wright to abandon the project.

1911 The area is worked for a season by the state mining and prospecting officer, Lala Joti Prashad. Only gray and semitranslucent corundum is found, confirming the popular belief that the source is depleted.

1924 Noted Himalayan geologist Pandit Labhu Ram Badyal undertakes a detailed mapping of the area, and announces the discovery of several occurrences of sapphire (some pink).

1926 A prospecting license is granted to Lala Jagan Nath, who reopens the trench begun by Wright in 1907 . Over $60 \mathrm{~kg}$ of sapphirebearing corundum are removed from these "New Mines" until the license is revoked in 1927 for undisclosed "irregularities."

1927 Over $450 \mathrm{~kg}$ of rough corundum crystals are extracted from Lala Jagan Nath's trench in 15 days.

1937 Production of sapphire falls significantly, marking an end to the second phase of mining in Paddar.

1938- The lowest yields are reported during this 1943 period, undoubtedly a result of the outbreak of World War II.

1944 R. V. Gaines visits the deposits, gaining access from the south. The first Western geologist to visit the site in many years, he collects some specimens, which are later lost.

1945- Sporadic mining by private lessees. Al1951 though production is substantial, the stones are not as good as those found during the early years.

1952- The government of Kashmir mines the de1959 posits intermittently, mostly at an operating loss, while maintaining exclusive control of the mine.

1961 The Kashmir government's assistant geologist, P. L. Raina, compiles a detailed but confidential report on the Kashmir mines.

1969 The last public sale of rough sapphire to date takes place in Srinagar.

1970- Various agencies of the state and central 1979 governments, in turn, survey the deposits and formulate mining strategies, but no new developments occur. Most years, the production is not profitable. Helicopters are employed to transport the yield to processing centers further south. Few major stones appear in the government takings.

1979 Mining operations cease. The government once again considers negotiating a lease with closely scrutinized but independent operators. 


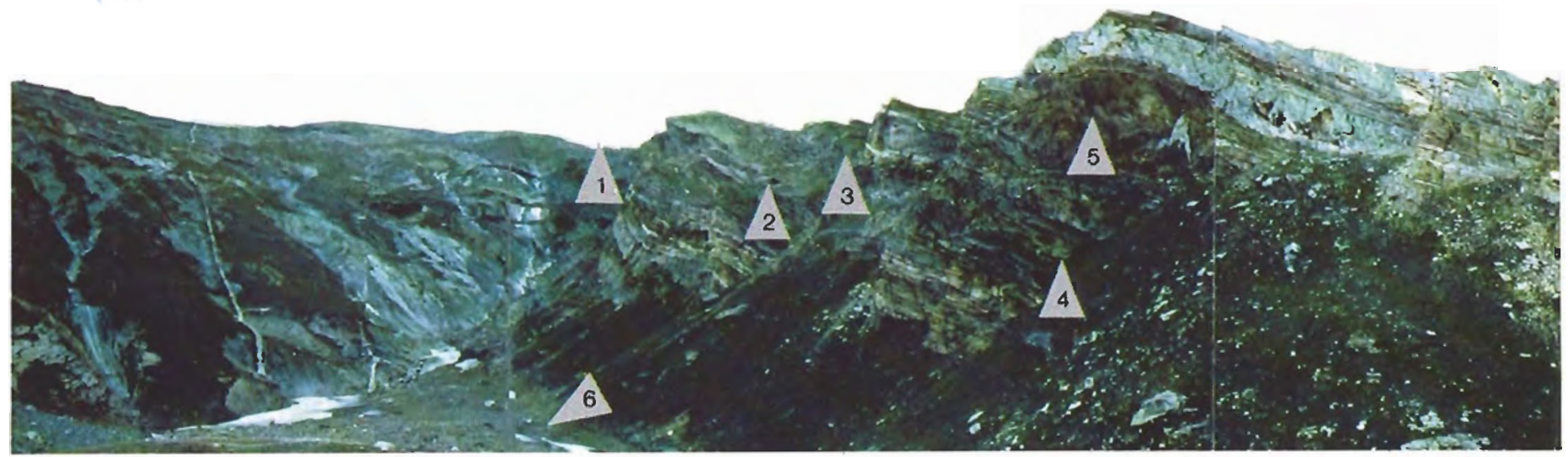

Figure 4. Panorama of the cirque in which the sapphires were first found, showing (1) Rubellite Mine, 4,650 m; (2) Old Mine, 4,500 m; (3) New Mines, 4,550 m; (4) burrows dug by early miners for shelter;

of the Geological Survey of India's deputy superintendent, T. D. La Touche, to carry out the first detailed survey and estimate of future potential. La Touche's results were presented in his landmark report of 1890 . Since then, only one comprehensive survey has been published (Middlemiss, 1931). Later surveys, undertaken by various government agencies since India's independence in 1947 and extending to the late 1970s, remain confidential.

On the recommendations of La Touche, crude washing troughs were constructed, using lumber carried from hundreds of meters below the mine. However, his attempts to exploit the alluvial deposits already discovered on the floor of the cirque at the base of the Old Mine yielded only one spectacular stone, and the mine was abandoned for 16 years until the government leased the prospect to private interests (Minerals Yearbook, 1906). It is evident from the frequent change in lessees that followed that the combination of impossibly harsh mining conditions, constant raiding by unauthorized parties, and the lack of major crystals made mining less and less attractive. Nevertheless, several interesting developments during this period pointed the way to future potential for the mines. La Touche had reported finding loose blocks of corundum in matrix on the north slope behind the old Mine, known as the "back slope" (see figure 5), but was unable to trace this material to its exact source. In addition, he postulated the existence of further

Figure 5. Schematic cross section through the northeast wall of Kudi Valley shows pegmatite lenses distributed through the altered marble (actinolite-tremolite). Only those lenticles at the surface have been excavated. After Middlemiss, 1931.

S.W.
$\begin{aligned} & \text { m above } \\ & \text { sea level }\end{aligned}$




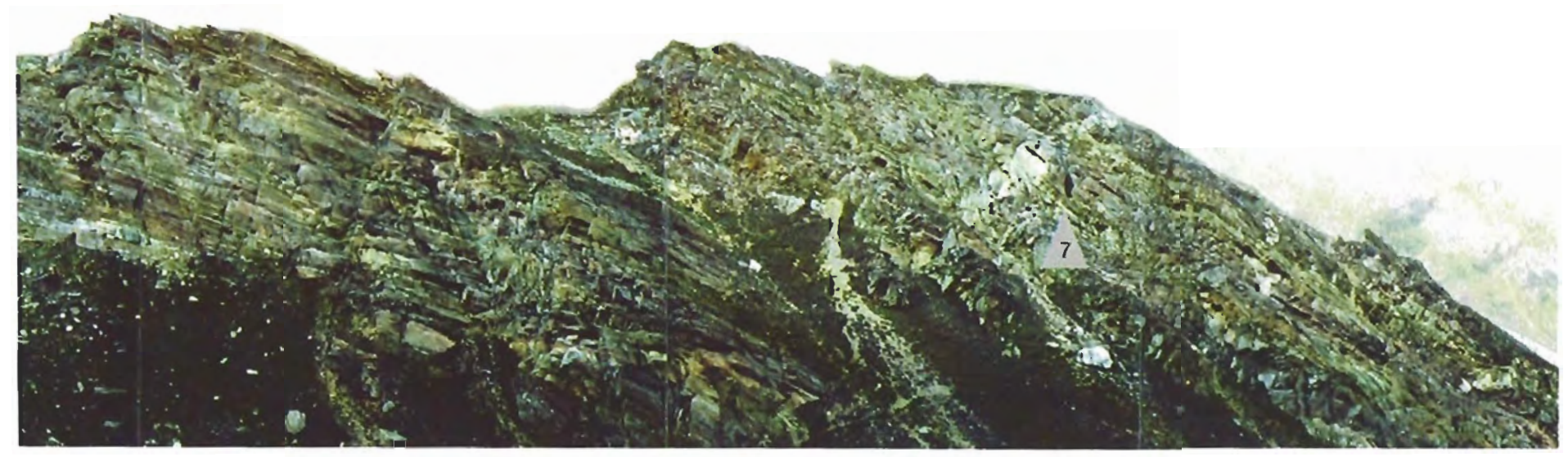

(5) geologically important actinolite-tremolite body; (6) placers; and (7) typical pegmatite intrusion with large pegmatite boulder below. From photos by $R$. Kothavala.

placer deposits beneath the floor of the cirque. To this day, no success has been reported in finding these deposits. In 1906, C. M. P. Wright, of the Kashmir Mining Company, lessee of the mine, reworked the earlier placer deposit with some success before abandoning the mines in 1908. On his departure, he did report several occurrences of new sapphire outcrops only a few hundred meters from the exhausted Old Mine. In his opinion, however, they were of little significance (Middlemiss, 1931).

The failure of sporadic mining during the next decade to produce any exciting crystals seemed to confirm the belief that the sapphire workings at Sumjam had finally been depleted. Nevertheless, in 1924 the government commissioned a detailed mapping of the area, and several new sapphire outcrops were identified. In the years that followed, a second phase of mining was begun at the "New Mines" (again, see figure 4). The results, although not as spectacular as earlier, were most profitable for the private operators-so much so, it appears, that the government decided to take matters into its own hands once more. In 1927, for undisclosed "irregularities," the mining lease was revoked and state mining laws were hastily revised (Middlemiss, 1931). A government-controlled mining project carried out that year yielded the largest seasonal production in the history of the area (see table 1). Proposals for a state gemcutting operation were drawn up, and a revival of the sapphire industry seemed imminent. In 1928, however, an experimental batch of rough was cut in Delhi and the results analyzed. Of over $900 \mathrm{ct}$ of finished stones, fewer than 20 pieces could be classed as excellent quality, only two as large as
TABLE 1. Production (in kilograms) of rough corundum in Kashmir from 1888 to 1951 . $^{\text {a }}$

\begin{tabular}{ccc}
\hline Season & From placers & From New Mines \\
\hline 1888 & 19.0 & - \\
1907 & 12.1 & 51.3 \\
1908 & 3.0 & 27.8 \\
1926 & - & 64.2 \\
1927 & - & 455.2 \\
1928 & - & 40.1 \\
1933 & - & 287.0 \\
1934 & - & 215.0 \\
1935 & - & 160.0 \\
1937 & - & 37.0 \\
1938 & - & $<1.0$ \\
1943 & - & 12.0 \\
1945 & - & 73.2 \\
1946 & - & 122.1 \\
1949 & - & 211.1 \\
1950 & - & 28.1 \\
1951 & - & 60.1 \\
\hline
\end{tabular}

a Table compiled trom various sources (La Touche, 1890; Holland, 1930; Middlemiss, 1931; Minerals Yearbook, 1935-1940; Coggin Brown, 1956). No exact details are available on what percentage of these mine runs were gem crystals, but all of the sources quoted agree that this percentage declined steadily atter 1908.

$6 \mathrm{ct}$ and one of $10 \mathrm{ct}$ (Middlemiss, 1931).

The new material could not compare with the early stones. Tenders were therefore accepted once more from private parties, and scanty reports suggest that at least three different operators worked the mines until 1951. Despite large quantities of rough extracted (over one million carats in 1949, when 50 workers were employed full time during the season) only a minute quantity of "incom- 


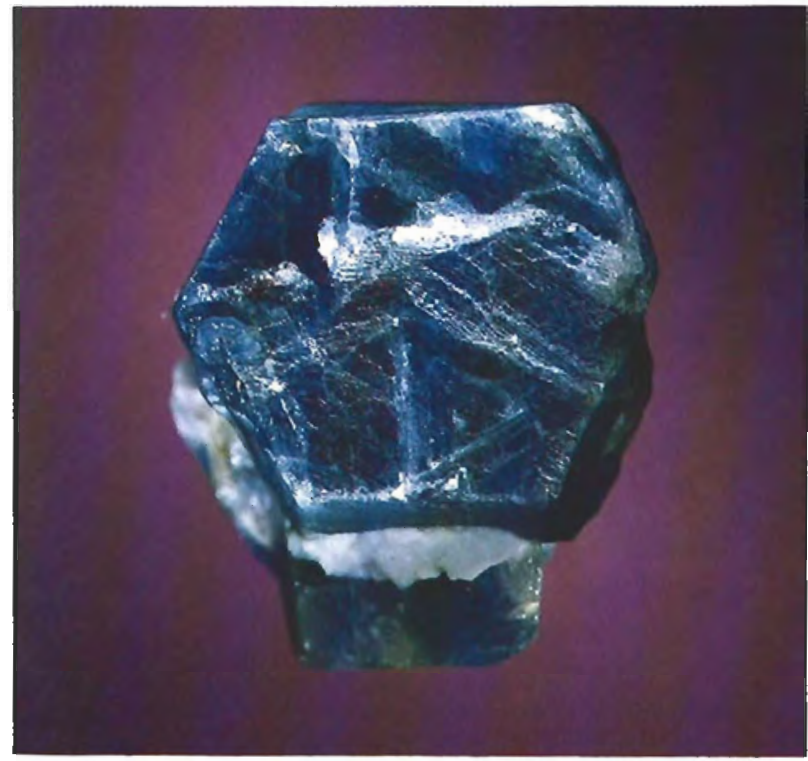

Figure 6. Large, well-formed but opaque corundum has been found at the foot of Hagshu glacier $15 \mathrm{~km}$ from the mines, but has never been traced to its exact source. This crystal measures $5 \mathrm{~cm} \times 3 \mathrm{~cm}$. Photo by Van Pelt.

parable" stones emerged. With the final dismantling of the maharajah's political power in 1967, the last connections between the maharajah of Kashmir and the Paddar mines were broken. Effective control of the mines now rests with the state government of Jammu and Kashmir. Over the past 30 years mining has been intermittent. In 1981 the mines were inactive, although at the time of writing negotiations are once again under way to lease the area to private interests.

\section{GEOLOGY}

The Zanskar Range occurs in an area of discontinuity in the Great Himalayan mountain range and is separated from the Karakoram and Hindu Kush ranges by the feature known as the Indus suture, through which the Indus River flows. Although very little is known about the crystalline rocks of Zanskar, the local formations bear many similarities to those of the Hunza Valley, $350 \mathrm{~km}$ to the north, which was recently described by Gübelin (1982). One important difference is the age of the metamorphics, which are CambroSilurian (Lydekker, 1883), as distinct from the younger Eocene rocks of the Karakoram Range (Gansser, 1964).

The mineralogy of the Paddar deposit is relatively simple but appears to be unique among known sapphire occurrences. Medium-grade metamorphic strata of coarse marble up to $30 \mathrm{~m}$ thick, locally interbedded with biotite gneisses and schists, make up the steep ridge near the top of which the mines are located (again, see figure 5). These gneisses are alternately graphite and hornblende rich, and rather dramatic examples of metamorphic crystallization abound. Elsewhere, the gneisses are gametiferous. One specimen collected from the floor of the cirque displays garnet crystals (weathered) of fine color up to $2.5 \mathrm{~cm}$ across in biotite schist. At various places, the marble appears to have undergone local modification, forming lens-shaped bodies of actinolite and tremolite. These lenses consist of felted and radiating aggregate crystals that vary in color from an olive green to a bright mint green. The lenses range from approximately one meter to hundreds of meters long and $30 \mathrm{~m}$ thick. A huge actinolite/ tremolite "eye" is clearly visible, surrounded by marble, in the panorama of the cirque shown in figure 4.

In many places along the mines ridge, the stratified beds are intruded by feldspar pegmatites. Where these intrusions are quartz-free and surrounded by the actinolite-tremolite bodies, sapphires occur in the greatest concentration. The corundum crystals are found in lenticles or discshaped pockets of plagioclase feldspar which has been kaolinized. Although these pockets are usually only approximately $1 \mathrm{~m}$ thick and 3 to $4 \mathrm{~m}$ long, the sapphires "occur as thickly as plums in a pudding" (Middlemiss, 1931). Here and there at depth, the weathered china clay gives way to solid pegmatite, which required the use of dynamite in later years (see "Mines" below). The lenticular intrusions appear to be quite pervasive and have been located on the slopes behind the mines ridge, where they show no signs of kaolinization. On this "back slope," and in several other places as far as $14 \mathrm{~km}$ from the mine, blocks of pegmatite containing corundum (figure 6) have been found, though they rarely have been traced to their actual source. Such blocks of "corundiferous granite" (La Touche, 1890) suggest that further gem deposits may someday come to light. During the 1981 expedition, a sample of pegmatite was found in which corundum crystals up to $2.5 \mathrm{~cm}$ in length form over $60 \%$ of the rock. This was collected on the floor of the cirque and almost certainly came from some point high on the mines ridge. At the extreme right of figure 4 can be seen an enormous block of pegmatite. 
Several reports have been made of corundum crystals found in contact with the bordering graphite biotite gneisses, and it is in these instances that the pink sapphire crystals /rare in this locality) have been observed (Middlemiss, 1931). Such a cluster of pink sapphire crystals is pictured in figure 7 next to a more typical blue crystal. References to rubies found in the Paddar district are few (e.g., Shepard, 1883). Although such occurrences are not unlikely, these reports remain unverified.

Several associated pegmatite minerals have been recovered from the mines and surrounding areas. Most notable among these are rubellite up to $7.5 \mathrm{~cm}$ in length /found at a locality only $300 \mathrm{~m}$ from the Old Mine), and green tourmaline up to $2.5 \mathrm{~cm}$ in length and aquamarine up to $20 \mathrm{~cm}$ in length and $7.5 \mathrm{~cm}$ in diameter (found at various localities|. Since none of these gem materials has been found in quantity, they have never been seen as potentially profitable. Rare examples of such crystals are pictured in figure 8 . Other reported mineral occurrences include hambergite (Burton, 1913), cookeite, prehnite, amblygonite, lazulite, amethyst (Mallett, 1905), black and brown tourmaline (Bauer, 1906), kyanite associated with quartz (La Touche, 1890), and fluorite (Middlemiss, 1931). Occurrences of spodumene and green euclase described by La Touche (1890) were later found to be amblygonite (Mallett, 1905) and tourmaline (Gaines, 1951), respectively. It has also been noted that the important actinolite/tremolite formation is a common feature of the regional geology (Middlemiss, 1931). The implications are

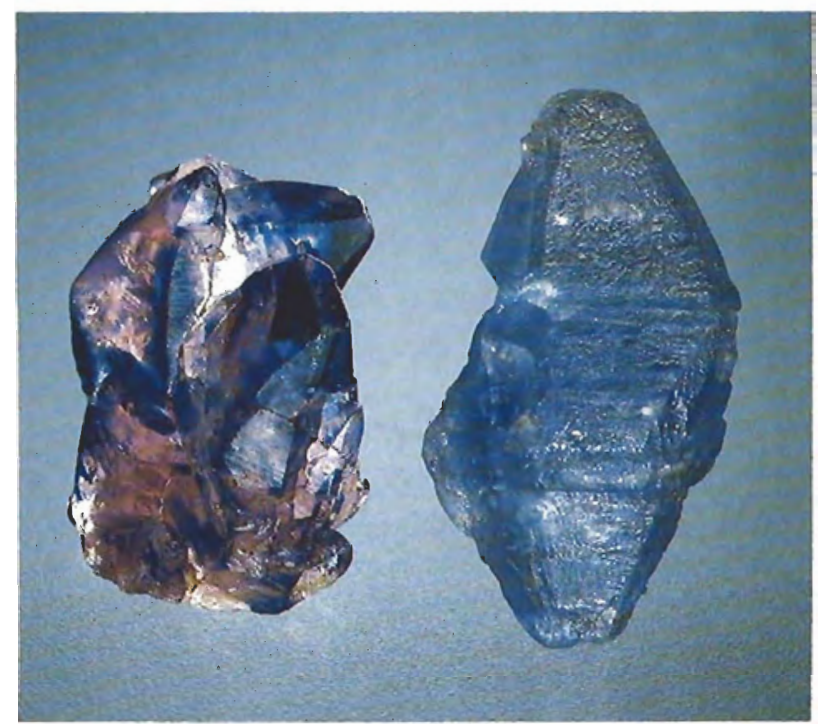

Figure 7. Rare examples of crystals from Kashmir that have escaped cutting. The cluster of pink crystals with blue tips $(2 \mathrm{~cm} \times 1 \mathrm{~cm})$ is typical of material found close to biotite schists (specimen courtesy of R. V. Gaines). The pale blue crystal on the right $(2.5 \mathrm{~cm} \times$ $1 \mathrm{~cm})$ is typical of the material found in the alluvial placers. Photo by Van Pelt.

clear: further deposits of sapphire and more common pegmatite minerals are certain to exist in the area. Their discovery, however, may be delayed indefinitely by the treacherous terrain and long, harsh winters.

\section{THE MINES}

The mines are situated in the northeast wall

Figure 8. Aquamarine and tourmaline have been found in Kudi Valley. The crystals pictured are from another locality only $8 \mathrm{~km}$ from the sapphire mines. An included crystal of black tourmaline can be seen within the aquamarine. Tourmaline inclusions have also been observed in Kashmir sapphires. The aquamarine crystal pictured here is $10 \mathrm{~cm} \times$

$3.5 \mathrm{~cm}$. Specimens courtesy of R. V. Gaines, Photo by Van Pelt.

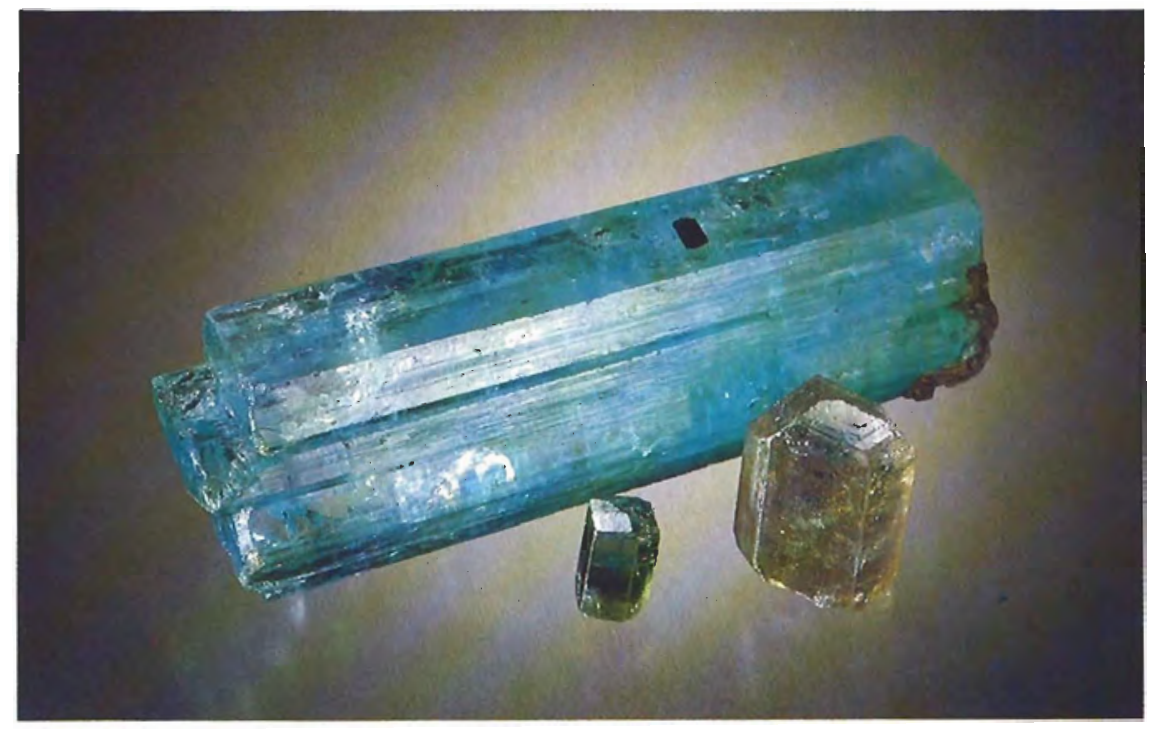




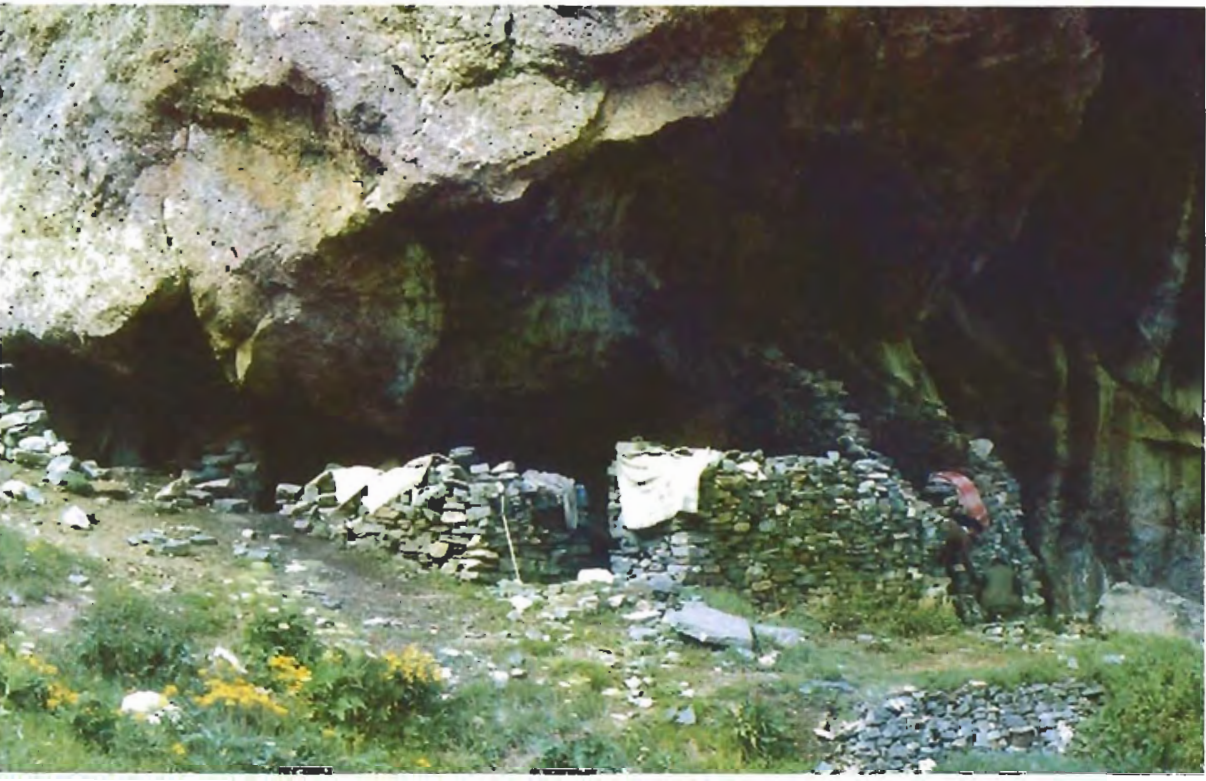

of a small glacial cirque known as Kudi Valley, approximately $1,000 \mathrm{~m}$ long and $400 \mathrm{~m}$ wide $\left(33^{\circ} 26^{\prime} 40^{\prime \prime} \mathrm{N}, 76^{\circ} 23^{\prime} 14^{\prime \prime} \mathrm{E}\right)$. On both sides, the stratified cliffs rise to a height of over $4,500 \mathrm{~m}$ near the level of perpetual snow. The floor of the valley, at $4,100 \mathrm{~m}$, is covered with scree and talus of unknown depth. The only known placer deposit was found on the north side of this valley in a depression directly below the mines. Dominating the mouth of this hanging valley and giving it its name is Kudi ("rock" in the local dialect), an enormous monolith. Beneath an overhanging portion of this rock, the small corral-like enclosures that serve as the Kudi police post overlook the precipitous $1,000-\mathrm{m}$ slope that is the only approach to the mines (figure 9). The nearest village is Sumjam, a dreary collection of seven huts $3.2 \mathrm{~km}$ to the east and about a thousand meters lower (figure 10).

With no roof, often engulfed in clouds, a contingent of four policemen maintain a constant vigil of the mines under miserably harsh conditions. During years when the mines are operative, miners pitch camp nearby. The burrows dug into the cliffs by early laborers for shelter (La Touche, 1890 ) are still visible today (again, see figure 4). Elsewhere in the valley are the ruins of former police shelters. The guard station near the top of the mines ridge, referred to by Gaines (1951) as the "black house," has since burned to the ground. As already observed, the local Paddaris harbor no great affection for the government police. Consequently, all of their supplies must be carried from the police post at Machel, $8 \mathrm{~km}$ away. Even to gather firewood, the guards must clamber down over $600 \mathrm{~m}$ to the tree line, where a few scrubby birch trees have taken root on the barren slopes. Since the Paddaris refuse to work the deposits, all mining labor must be imported from neighboring districts. Access to the valley of Paddar is over tortuous tracks, rarely more than a meter wide. In many places, this trail crosses narrow bridges or is cut into sheer rock faces which drop away over $300 \mathrm{~m}$ to the roaring river below (figure 11).

In 1981, because of official obstacles and an exceptionally rainy summer, it took eight strenuous days to make the journey of some $110 \mathrm{~km}$ between Kishtwar and Sumjam. The route is difficult and the mining season is short. The snows usually melt in late June and begin again in late September, but several seasons have been reported where mining was confined to 15 days or less (Middlemiss, 1931). Consequently, the high wages necessary to entice workers into these circumstances further decrease the profitability of large-scale mining efforts. Under such conditions, it is little wonder that mining has been haphazard. The most advanced techniques used to date have been those involving hand augers, blasting, and washing.

Following is a list of mining areas in Kudi Valley; their locations can be seen in figure 4:

Old Mine. An insignificant pit at $4,500 \mathrm{~m}$ $(14,775 \mathrm{ft}\}$ is all that remains of the small pocket that produced so many fine stones. The crystals were worked from the soft china clay by hand and using hand tools. Early reports likened the work to "digging for potatoes" (Mallett, 1882). The crystals typically were large and covered by a tenacious coating of kaolin. After the stones were 


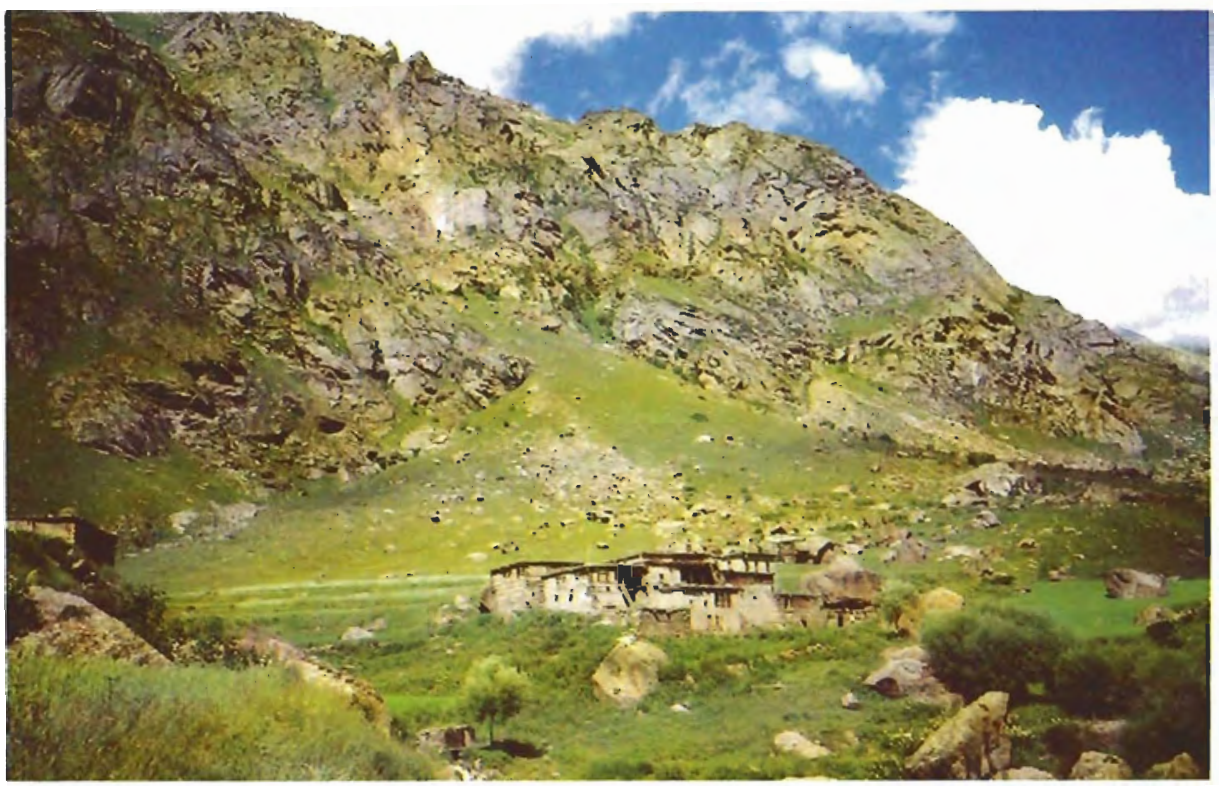

Figure 10. Sumjam, at an elevation of $3,100 \mathrm{~m}$, is the last outpost of civilization in Paddar, and consists of seven adobe huts housing five families. Photo by Meher.

cleaned, they were observed to be heavily zoned but with large gemmy portions.

New Mines. Only a hundred or so meters away are a series of adits at $4,550 \mathrm{~m}$. They are distributed over a small area "about as large as the foundation of a small house" (Middlemiss, 1931). In recent times, much blasting has been done here. Typically, the percentage of gem corundum found in this deposit is lower than that taken from the Old Mine and the crystals are smaller $(2.5-5 \mathrm{~cm})$. Rare occurrences of the pink sapphires mentioned earlier have been reported from these mines. The concentration of crystals is high, approximately $20 \%$ of the pegmatite host. According to Middlemiss, one shovelful typically would yield eight crystals. The adits are heavily barred and locked. The extent of the deposit is not known.

Placers. By bringing water from a nearby spring to bear on one section of the valley floor, La Touche (1887-1889) and later Wright (1906-1908) were able to find some large stones. An expedition dispatched from Srinagar in 1928 to look for new placer deposits returned empty-handed. Apparently misreading La Touche's maps, the mining engineer dug for the placer deposits on the steep slopes rather than on the valley floor. Amazingly, no more is known today about the valley floor than when Wright left in 1908. This is undoubtedly due to the difficulty of searching systematically without machinery. Pits from abandoned placer workings were still visible in 1981 .

Rubellite Mine. Crystals of rubellite up to $7.5 \mathrm{~cm}$ long have been reported from this mine, which lies approximately $275 \mathrm{~m}$ from the Old
Figure 11. Access to the Kashmir mines requires traveling over more than $100 \mathrm{~km}$ of treacherous foot and pony trails. Narrow bridges such as this one, $300 \mathrm{~m}$ above a tributary of the Ghenab River, are common. Photo by $R$. Kothavala.

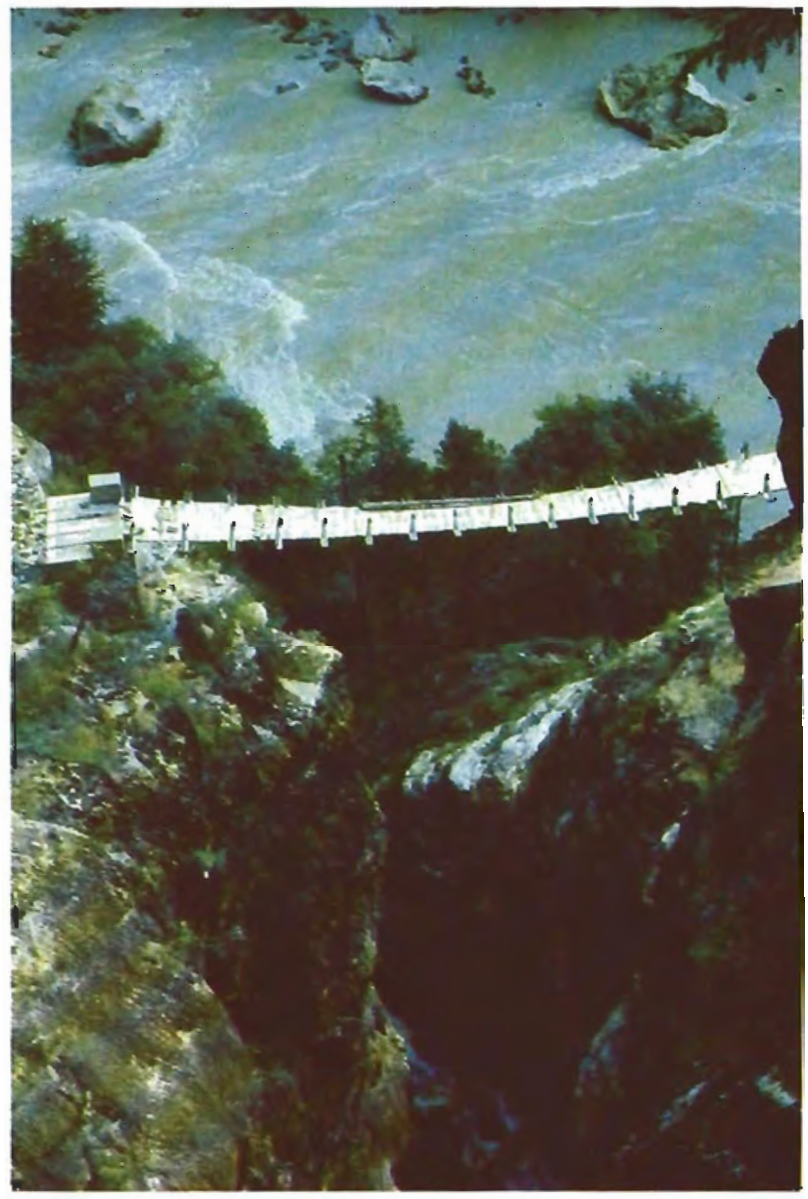


Mine at 4,650 $\mathrm{m}(15,250 \mathrm{ft})$. However, they do not occur in any quantity, and the site is often covered by snow and ice year round. Therefore, little is known about the extent of the deposit.

Back Slope. The excavation of pegmatite outcroppings on the slope behind the mines has so far failed to reveal any major pockets.

Some nearby localities are:

Hagshu. Little has been said of the large corundum crystals found at the foot of the Hagshu glacier by La Touche in 1887. Although this locality is only $15 \mathrm{~km}$ from Kudi Valley, the pegmatite vein has never been traced. It is believed to be somewhere in the inaccessible cliffs above. An example of the well-formed but opaque Hagshu corundum appears in figure 6 .

Dangel. Only about $4 \mathrm{~km}$ southeast of Sumjam fragments of sapphire and aquamarine have been found on the slopes (Middlemiss, 1931). These have been traced to a pegmatite vein in the cliffs at $3,350 \mathrm{~m}(11,000 \mathrm{ft})$. Inasmuch as the fragments found here were small, the commercial prospects of this locality have not been explored.

Machel, Chishote. Aquamarine has been found elsewhere in Paddar, near these two villages, which are $8 \mathrm{~km}$ and $20 \mathrm{~km}$, respectively, from Sumjam (Middlemiss, 1931). Again, little is known about these localities.

\section{GEMOLOGY OF THE KASHMIR SAPPHIRES}

Kashmir sapphires are, almost without exception, zoned. This distribution of color is usually associated with microscopic layers of liquid inclusions, which are responsible for the typical velvety luster known in the gem trade as "sleep" (see figure 1). An example of color zoning and the hazy effect produced by the accompanying tiny droplets of liquid can be seen in figure 12 .

One rather ingenious method of approximating the Kashmir texture in a blue sapphire from another locality involves cutting the pavilion with a fine lap and leaving it unpolished, while polishing the crown and table in the normal manner. The rough pavilion is easily detected on close examination. The blue of the finest Kashmir sapphires, which is referred to in India as "peacock's neck," seems to lack the secondary modifiers of green and pink that are seen in so many other blue sapphires. Consequently, Kashmir stones have long been observed to maintain their vivid blue color under varied lighting conditions. Star sapphires from Kashmir are reportedly of superb quality, but they are exceedingly rare (HadfordWatkins, 1935).

Gemological Properties. A study of the 6.70-ct Kashmir sapphire from the Hixon Collection at the Los Angeles County Museum of Natural History (pictured in figure 1) showed the physical and optical constants to be quite normal for corundum: specific gravity, 4.03; refractive index, 1.762-1.770; inert to ultraviolet radiation; a weak red fluorescence to X-radiation; spectrum showing a weak absorption line at $450 \mathrm{~nm}(\mathrm{Fe})$ and in the red $(\mathrm{Cr})$.

Inclusions. The reader is referred to Phukan's article (1966) for a comprehensive list of inclusions, with photographs, reported in a sample of nine Kashmir stones. By far the most common were the feather-like inclusions mentioned above. Flat films filled with a brown or yellowish liquid were also found to characterize Kashmir stones, and the fingerprint inclusions so common in Sri Lankan sapphires were observed in the Kashmir stones as well. Of particular significance are the opaque black prismatic crystals mentioned by Phukan. These would seem to confirm the early descriptions of cavities containing tourmaline prisms inside some corundum crystals from Kashmir. The most unusual of the recorded cavities contained a small, transparent tourmaline prism, which was light brown with an indicolite termination (Mallett, 1882). The black inclusion in the aquamarine crystal of figure 8 is a doubly terminated and flattened crystal of tourmaline, the c-axis of which runs perpendicular to that of the host. The occurrence of zircon crystals both with and without their usual accompanying strain halos are also of interest. Other solid inclusions observed, such as long, fine rutile needles and dust-like particles, are common to other localities as well. To summarize, the most widespread internal characteristics of Kashmir stones are zoning, liquid feathers, and flat brownish or yellowish liquid films.

\section{FAMOUS KASHMIR SAPPHIRES}

Compared to the Badakhshan mines of Afghanistan, the Mogok mines of Burma, and the Panna mines of India, the Kashmir deposits are in their infancy. It is therefore not surprising that the whereabouts of few famous Kashmir stones are known. We must remember that the Paddar deposits have produced major gems only very spo- 


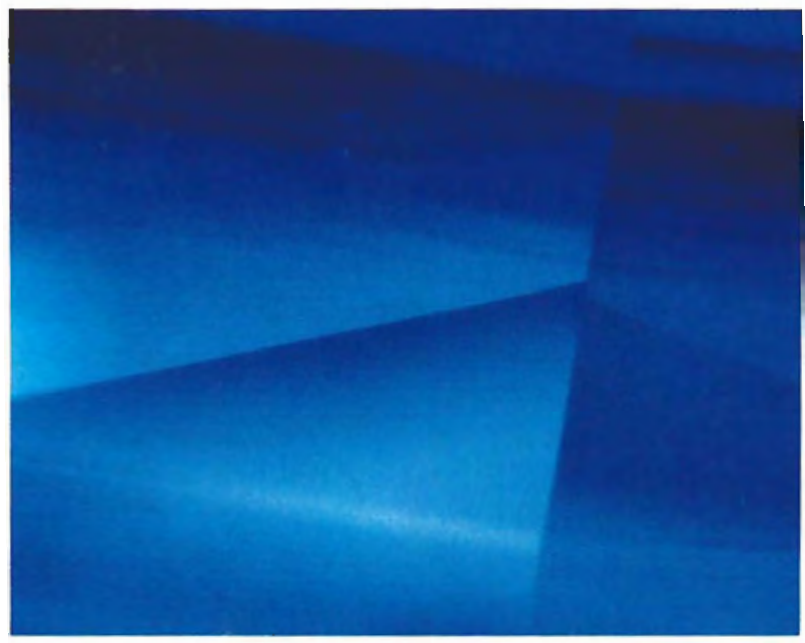

Figure 12. The zoning and hazy effect so common in Kashmir sapphires is seen in this photo of the Hixon sapphire. Magnified $20 \times$. Photomicrograph by John Koivula.

radically, during an era of declining British influence in the Indian Empire. The rulers in the fiercely.independent dominion of Kashmir were widely accepted as being above British law, and therefore immune from many of the tributary pressures usually incumbent on subjects of colonial empires. Those who wished to acquire remarkable Kashmir sapphires would most certainly have to pay for them. The closely guarded collection of prize crystals and faceted stones housed in the toshakhana, or State Treasury, was seen only by a privileged few. Some of the more important pieces are described here.

La Touche $(1890)$ reports seeing several crystals about $12.5 \times 7.5 \mathrm{~cm}(5 \times 3$ in. $)$ that were blue and transparent in the center fading to colorless at the ends. Such crystals undoubtedly weighed thousands of carats. Of rough crystals, the largest and most impressive was a fragment almost spherical in shape and of a deep blue color, estimated to be "larger than a croquet ball." Many cases of cut stones of fine color "superficially as large as florins" were also described (Middlemiss, 1931). One can only surmise that such stones weighed over $20 \mathrm{ct}$. Several witnesses report large crystals in the possession of certain government officials in the 1880s (Mallett, 1882). Their whereabouts are now unknown. In 1887, La Touche exposed a gemmy crystal weighing over $930 \mathrm{ct}$. in the washings of the placers. Whether this was ever cut has not been recorded. Certainly, the royal jewels of the maharajahs of Kash- mir and Jaipur were known to contain breathtaking examples. This is presumably still the case. Over the years, as production of large stones dwindled, the disposition of new important stones became less and less public. The presentation in 1934 by the Duke of Kent to Princess Marina of an engagement ring set with a large, square-cut Kashmir sapphire focused the attention of international jewelers on these stones, which were already in short supply (Hadford-Watkins, 1935). Few examples of rough or faceted Kashmir sapphires are on display in the major museums of the world.

The following account serves to illustrate the current availability of Kashmir stones over 20 ct. In early 1980, a leading authority and supplier of gem sapphires in the United States was nonplussed to receive rather urgent requests from a dozen different sources for a fine cushion-cut Kashmir sapphire of $25 \mathrm{ct}$. After leaming that the sapphire was intended as a gift at a certain royal wedding, the dealer redoubled his efforts to locate a suitable stone. Only two pieces could be located, one of which was patently unavailable. Notwithstanding the auspicious circumstances, negotiations for the other stone broke down and the order was never filled (R. Miller, 1982, personal communication).

\section{THE CURRENT SITUATION}

The mines are not operating at this time. Permission to work the site falls under the jurisdiction of the Directorate of Mining and Geology, Jammu and Kashmir government, and a police guard maintains a year-round vigil at or near the site. In the past, gems have been sold at infrequent state government auctions. The most recent of these took place in Srinagar in 1969, where some $57,000 \mathrm{ct}$ of gem rough were sold (Australian Financial Review, 1969). Judging by the proceeds of this sale (approximately US $\$ 20,000$ ) the number of important pieces must have been low. Details of a previous sale in 1965 are not known.

As a result of the rapid decline in official mining activity over the past 30 years, more and more of today's trade in Kashmir sapphires is falling into the hands of the indigenous population (figure 13). The strict laws forbidding private trade in sapphires are a deterrent against any organized collecting or excavating. Nevertheless, every year a handful of fine stones found by shepherds on the hillsides make their way out of the Paddar Valley to be sold in Delhi. Probably because of the in- 


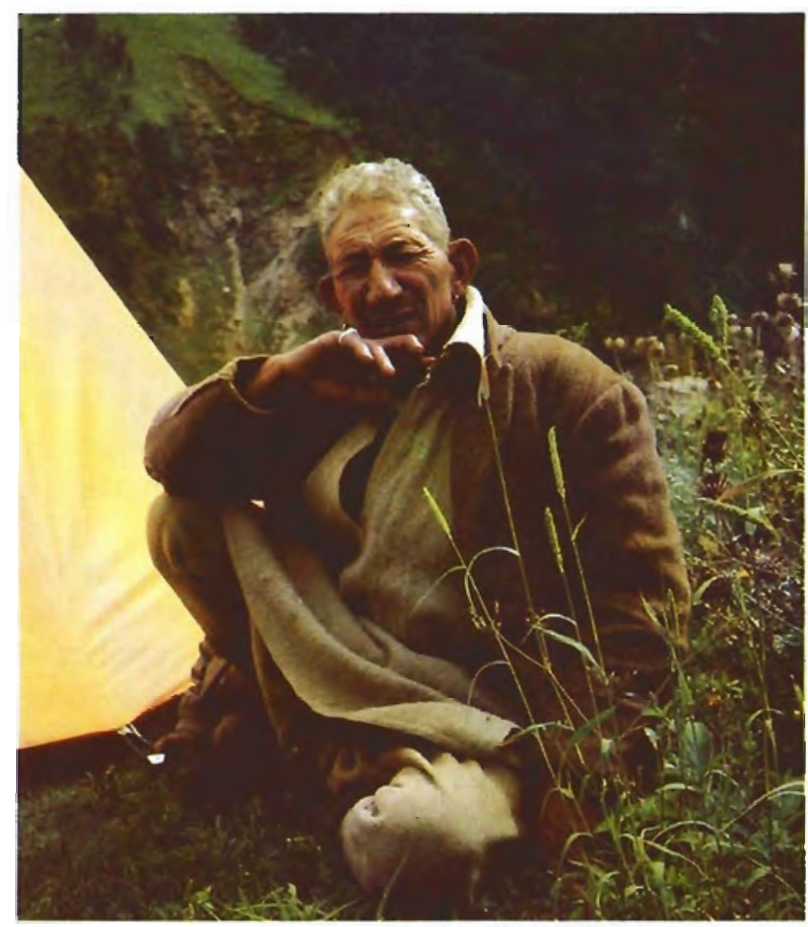

Figure 13. Production of Kashmir sapphires on a commercial scale today is nonexistent. Nevertheless, every year a trickle of fine gems finds its way to the world markets through the hands of the local people. Photo by Meher. volvement of government interests, the majority of fine Kashmirs have been marketed in the Indian capital rather than in the traditional gem center of Jaipur. How the gem sapphires find their way to buyers in Hong Kong, Switzerland, New York, and, until recently, Beirut is a closely guarded secret. From time to time, old cabochon pieces turn up on the market and are salvaged as faceted stones of considerable quality (R. Miller, personal communication, 1982/.

It is evident that several deposits of sapphire and other gem minerals await discovery in the Paddar district. The difficult access makes the task of systematic mining and exploration exceedingly complicated. Furthermore, the realistic potential of the Kashmir area is impeded by political factors. Since Pakistan's partition from India in 1947, the mountainous state has never been free from tension. This insecurity has been compounded by China's occupation of Tibet in 1950, two Indo-Pakistan wars, in 1965 and 1971, and Russia's invasion of Afghanistan in 1979. In such an atmosphere, exploitation of mineral deposits is secondary to political and military preoccupations. Until this situation changes, we must expect that the appreciation and demand for fine Kashmirs will be maintained by their great rarity.

\section{REFERENCES}

Australian Financial Review (1969) Kashmir. October 16, p. 35.

Bauer M. (I 906) Precious Stones. Translated by L. J. Spencer, Tuttle Publishing, Rutland, VT, 1969.

Burton R.C. (1913) Note on a twinned crystal of hambergite from Kashmir. Records of the Geological Survey of India, Vol. 43, pp. 168-172.

Coggin Brown J. (1956) Sapphires of India and Kashmir. The Gemmologist, Vol. 25, No. 298, pp. 77-80; No. 299, pp $97-100$; No. 300 , pp. 129-132.

Gaines R.V. (1946) The Kashmir Sappire Mines. Himalayan Journal, Vol. 13, pp. 73-77.

Gaines R.V. (195I) The sapphire mines of Kashmir. Rocks \&) Minerals, Vol. 26, p. 464.

Gansser A. (1964) Geology of the Himalayas. John Wiley \& Sons, New York, NY.

Gübelin E.J. (1982) Gemstones of Pakistan: emerald, ruby, and spinel. Gems \&) Gemology, Vol. 18, No. 3, pp. 123-139.

Hadford-Watkins J.F. (1935) Kashmir sapphires. The Gemmologist, Vol. 4, No. 42, pp. 167-172.

Holland T. (1930) Mineral production of India 1924-28. Rec- ords of the Geological Survey of India, Vol. 64, p. 275.

La Touche T.D. (1890) The sapphire mines of Kashmir. Records of the Geological Survey of India, Vol. 23, pp. 59-69.

Lydekker L. (1883) Geology of Kashmir and Chamba. Memoirs of the Geological Survey of India, Vol. 22, pp, 335-336.

Mallett F.R. (1882) On sapphires recently discovered in the northwest Himalaya. Records of the Geological Survey of India, Vol. 15, pp. 138-141.

Mallett F.R. (1905) On the occurrence of amblygonite in Kashmir. Records of the Geological Survey of India, Vol. 32, pp. $228-229$

Middlemiss C.S. (1931) Precious and semi-precious gemstones of Jammu and Kashmir. Minerol Survey Reports, Jammu and Kashmir Government.

Minerals Yearbook (1906, 1935, 1936, 1937, 1939, 1940). U.S. Geological Survey, U.S. Department of the Interior.

Phukan S. (1966) Studies on inclusions in some lndian gemstones. Tournal of Gemmology, Vol. 10, No. 1, pp. 1-7.

Shepard C.V. (1883) Notice of corundum gems in the Himalaya region of India. American lournal of Science, Vol. 126, pp. 339-340. 